DOI 10.30740/jee.v1i1.p45-50

\title{
APPLICATION RECIPROCAL TEACHING IN BUILDING OF STUDENTS' MATHEMATICAL CONNECTION ABILITY
}

\author{
Aang Rohimat ${ }^{1}$, Rosalina Rolina ${ }^{2}$ \\ ${ }^{1}$ SMPN 2 Margaasih \\ ${ }^{2}$ SMK TI Pembangunan Cimahi \\ ${ }^{1}$ aangrohimat1@gmail.com, ${ }^{2}$ maezarou@gmail.com
}

Received: January 08, 2018; Accepted: June 30, 2018

\begin{abstract}
This research is motivated by the lack of connection capabilities junior high school students in Bandung West. This study will examine the achievement of matemati connection capabilities of students usinglearning reciprocalteaching with the usual approach. The method used is an experimental method to design pretest-posttest control group, ie design involving at least two groups and randomly sampling classes. At the beginning and end of the study both classes were given the test. The population in this sample is the entire junior high school students in Bandung West whose characteristics have a low ability mathematical connections. Of the entire junior high school in West Bandung randomly selected and elected SMP Negeri Bandung Barat representing the characteristics of the population. The sample was selected randomly, where class G into the experimental class VIII, and VIII F be the class of the control. Collecting data in this study using a test description that has been tested first, and then score the mathematical connection capabilities of students were analyzed by descriptive and inferential statistics using two different test average. Based on the results, good data analysis and hypothesis testing, with $\alpha=0.05$ mathematical connection capability turns the achievement of students usinglearning model reciprocal teaching is better than the students who used the usual approach
\end{abstract}

Keywords: mathematical connection, reciprocal teaching

\begin{abstract}
Abstrak
Penelitian ini dilatarbelakangi oleh rendahnya kemampuan koneksi siswa SMP di Bandung Barat. Penelitian ini akan menelaah pencapaian kemampuan koneksi matemati siswa yang menggunakan pembelajaran reciprocal teaching dengan pendekatan biasa. Metode yang digunakan adalah metode eksperimen dengan disain kelompok kontrol pretes-postes, yaitu disain yang melibatkan paling tidak dua kelompok dan pengambilan sampel secara acak kelas. Pada awal dan akhir pembelajaran kedua kelas diberi tes. Populasi dalam sampel ini adalah seluruh siswa SMP di Bandung Barat yang karakteristiknya memiliki kemampuan koneksi matematis yang rendah. Dari seluruh SMP di Bandung Barat dipilih secara acak dan terpilih SMP Negeri Bandung Barat yang mewakili karakteristik populasi. Sampel dipilih secara acak, di mana kelas VIII G menjadi kelas eksperimen, dan kelas VIII F menjadi kelas kontrol. Pengumpulan data dalam penelitian ini menggunakan tes uraian yang telah diujicobakan terlebih dahulu, kemudian skor kemampuan koneksi matematik siswa dianalisis dengan statistik deskriptif dan inferensial menggunakan uji perbedaan dua rata-rata. Berdasarkan hasil penelitian, baik analisis data maupun pengujian hipotesis, dengan $\alpha=0,05$ ternyata pencapaian kemampuan koneksi matematis siswa yang menggunakan model pembelajaran reciprocal teaching lebih baik daripada siswa yang menggunakan pendekatan biasa
\end{abstract}

Kata Kunci: koneksi matematis, reciprocal teaching 
How to Cite: Rohimat, A., \& Rolina, R. (2018). Application Reciprocal Teaching In Building Of Students' Mathematical Connection Ability. Journal of Educational Experts (JEE), 1 (1), 4550 .

\section{INTRODUCTION}

Ability mathematical connection is the fundamental ability to be possessed by the students. In mathematical connection capability is very important because it can help students to understand the inter-subject mathematics, applied mathematics concepts in other fields or in everyday life. This is supported by statements Suherman (Gunawan, 2013) which states, 'the ability to connect in mathematics is the ability to associate concepts or mathematical rules with each other, with other areas of study, or by an application on a real life'. Surveys conducted by the Program for International Student Assessment (PISA) in 2009 found that $69 \%$ of Indonesian students are only able to recognize the subject matter but was unable to find a link between the subject matter with the knowledge that has been owned. Ruspiani study (2000) revealed that the students' ability to perform mathematical connections is quite low. This is due to a lack of understanding of the concept of the students, so that students are difficult to associate the concept of inter math topics, matemtika connect with other subject areas, or associate the mathematical concepts to real life. To overcome these problems required the selection of appropriate learning approaches. One solution is to use the reciprocal teachingapproach.approach Reciprocal teaching or teachingis learning to apply reverse four comprehension strategies, which conclude and summarize materials, prepare questions and solve it, explain again the knowledge that has been gained, then predicts the next question on the issues being presented to the students. On approach to reciprocalteaching one strategy is to develop understanding of questions and solve it, then implement these strategies, students can connect mathematical concepts with other concepts. This shows the relationship between theapproach reciprocal teaching with mathematical connection capabilities.

Based on the description above, the researchers are interested in conducting research under the title "The Effect pengguanaan approach Reciprocal Teaching on the ability connected Mathematically Junior High School Students"

\section{METHOD}

The method used in this study is a quasi-experimental method, where the sample was not selected randomly. At the beginning and end of the study both classes were given the test, so dasain research is as follows (Ruseffendi, 2010: 53):

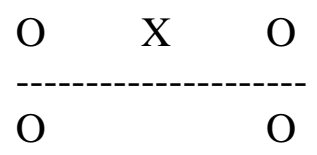

Description:

$\mathrm{O} \quad$ : Pretest $=$ postes (test mathematical connection capability)

$\mathrm{X} \quad$ : Learning to use theapproach reciprocal teaching

------ : Samples were not selected randomly. 


\section{DATA ANALYSIS AND DISCUSSION}

\section{Analysis of data}

Pretest and posttestgiven in each class, and then do the scoring for analysis using software IBM SPSS Statistics 20. Here are the results of output statistical testingdata description pretest and posttest experimental class and control class.

Table 1

Descriptions Statistics Score Score pretest andposttest Data Analysis pretest

\begin{tabular}{|c|c|c|c|c|c|c|c|c|c|c|}
\hline \multirow[t]{2}{*}{ Kelas } & \multicolumn{5}{|l|}{ Pretes } & \multicolumn{5}{|c|}{ Postes } \\
\hline & $\mathbf{N}$ & Rerata & $\begin{array}{l}\text { St. } \\
\text { Dev }\end{array}$ & Min & Mak & $\mathbf{N}$ & Rerata & $\begin{array}{l}\text { St. } \\
\text { Dev }\end{array}$ & Min & Mak \\
\hline Eksperimen & 32 & 6,43 & 1,480 & 5 & 10 & 32 & 8,56 & 2,663 & 5 & 16 \\
\hline Kontrol & 32 & 7,25 & 1,849 & 5 & 11 & 32 & 7,06 & 2,257 & 5 & 12 \\
\hline
\end{tabular}

Pretest was given to the experimental class and control class to determine the respective initial capability each class before teaching and learning activities done in class. Furthermore, the scoring against the pretest that was awarded in each class to be analyzed using software IBM SPSS Statistics 20.

Furthermore, the significant differences in the two mean test to determine differences in the ability of students' mathematical connections of each such class. Test normality of the data was conducted to determine the sample from the population that is normally distributed or not distributed normally usingstatistical test Shapiro Wilk with a level of $95 \%$ or significant $\propto=0,05$.

The following are the results of data processing pretest data normality test experimental class and control class pretest.

Table 2

Normality Test Datapretest

\begin{tabular}{lllllll}
\multicolumn{2}{l}{ Shapiro-Wilk } & & \multicolumn{4}{c}{ Kolmogorov-Smirnov ${ }^{\text {a }}$} \\
Sig. & df & Statisti & Sig. & df & Statistic & CLASS \\
& & c & & & &
\end{tabular}

\begin{tabular}{|c|c|c|c|c|c|c|c|}
\hline .209 & 32 & & .001 & 32 & .847 .000 & $\begin{array}{l}\text { EXPERIME } \\
\text { NTAL }\end{array}$ & SCORES \\
\hline .010 & 32 & .188 & & 32 & .006 .908 & CONTROL & \\
\hline
\end{tabular}

Based on the data in Table 15 shows that the Significant the experimental class is 0,000 a classand controls. 0,010 These values meet the criteria of the P-value $<0.05$ then H_o rejected, which means samples come from populations not normally distributed. Because the sample comes from a population that is not normally distributed, then continued with a significant test of the difference of two mean using non-parametric test of Mann-Whitney. The following are the results of data processing significant test two mean pretest pretest experimental class and control class. 
Table 3

\begin{tabular}{ll}
$\begin{array}{l}\text { Non Parametric Test Mann-Whitney } \\
\text { Score } \\
\text { pretest }\end{array}$ \\
\hline 383000 & Mann-Whitney U \\
911000 & test,Wilcoxon W \\
-1772 & $\mathrm{Z}$ \\
.076 & $\begin{array}{l}\text { Asymp. Sig. (2- } \\
\text { tailed) }\end{array}$ \\
\hline
\end{tabular}

Based on the data in Table 16 shows that the Significant is 0.076 . These values meet the criteria of the P-Value > 0,05 0.05 then H_o acceptable, which means there is no difference initial capability mathematical connections junior high school students are usingapproach reciprocal teaching that uses the usual learning at significant level 0.05. Posteswas given to the experimental class and control class for the final step of the learning process after being given a different treatment. Furthermore, the scoring against postes which was awarded in each class to be analyzed using software IBM SPSS Statistics 20. Furthermore, the significant differences in the two mean test to determine differences in the ability of students' mathematical connections of each such class. Test normality of the data was conducted to determine the sample from the population that is normally distributed or not distributed normally usingstatistical test Shapiro Wilk with a level of $95 \%$ or significant $\propto=0.05$.

The following are the results of data processing data normality test and post-test experimental class posttest control group.

Table 4

Postes Data Normality Test

\begin{tabular}{|c|c|c|c|c|c|c|c|}
\hline \multirow[b]{2}{*}{ Sig } & \multirow[b]{2}{*}{ Df } & \multirow[b]{2}{*}{$\begin{array}{l}\text { Stati } \\
\text { stic }\end{array}$} & \multicolumn{3}{|c|}{ Smirnov $^{\mathrm{a}}$} & \multirow{2}{*}{\multicolumn{2}{|c|}{ Class }} \\
\hline & & & Sig. & $\mathrm{d}$ & $\begin{array}{l}\text { Stati } \\
\text { stic }\end{array}$ & & \\
\hline $\begin{array}{l}.12 \\
2\end{array}$ & 32 & & $*$ & 2 & $\begin{array}{l}.200 \\
.937 \\
.064\end{array}$ & $\begin{array}{l}\text { experi } \\
\text { ment }\end{array}$ & Postes \\
\hline $\begin{array}{l}.21 \\
2\end{array}$ & 32 & & .001 & 2 & $\begin{array}{l}.837 \\
.000\end{array}$ & control & \\
\hline
\end{tabular}

Based on Table 17 shows that the experimental class is Significant to 0,064, while the control group 0,000.This means that for the class of experimental samples come from normally distributed population. As for the control class P-Value <0.05, the samples come from populations not normally distributed. 
Based on data normality test that the samples come from populations not normally distributed, then the non-parametric Mann Whitney test. The following are the results of data processing significant test two experimental class mean posttest and posttest control group.

\section{Table 5}

\section{Significant Non Parametric Test Mann-Whitney}

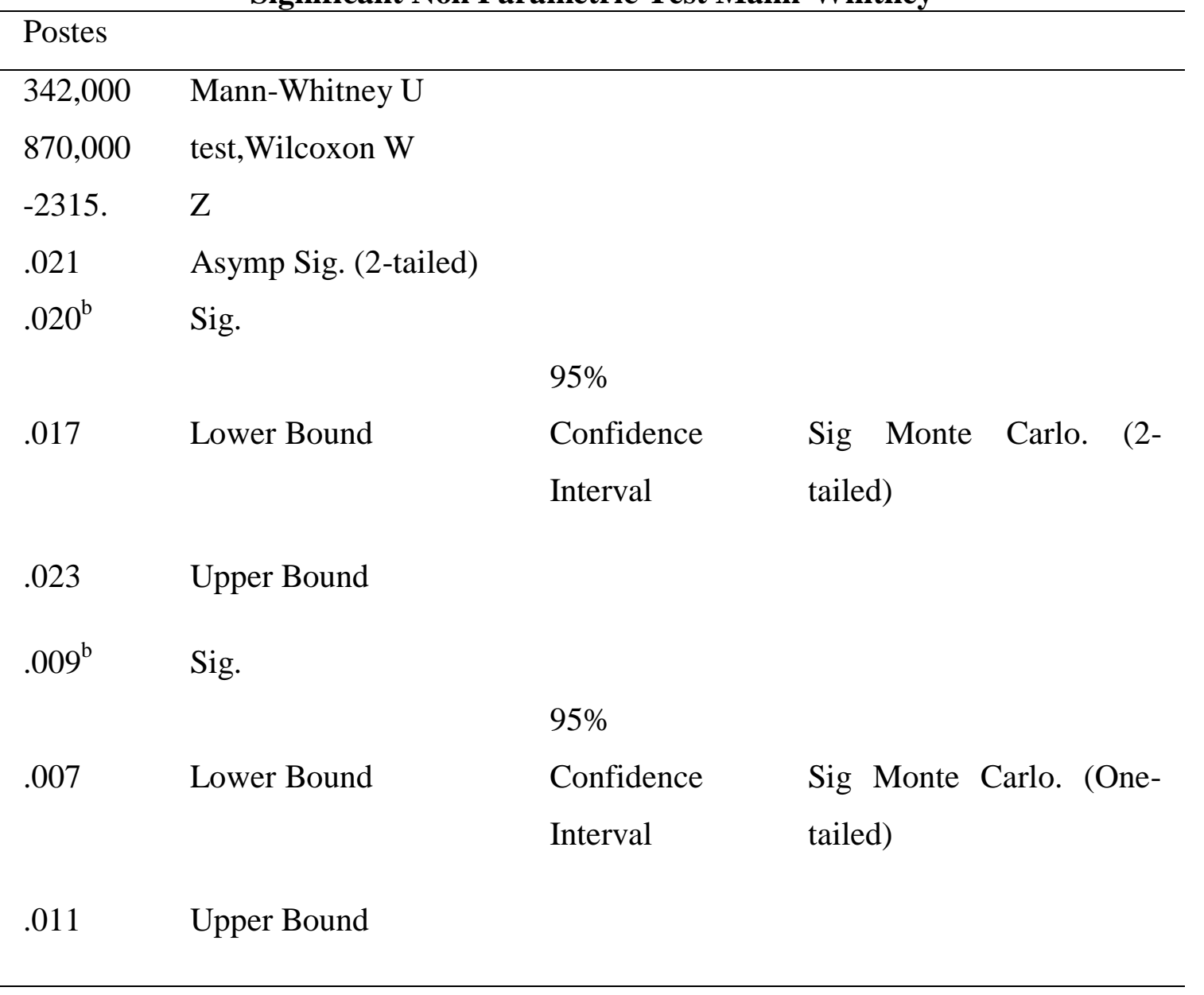

Based on Table 18 shows that the Significant is 0,021.These values should be halved for using software IBM SPSS Statistics 20. According Uyanto (2009: 145) that a significant display of SPSS is to test two parties(2-tailed),because we are going to test hypotheses one side(one tailed)then the value of Significant (2-tailed)should be halved. Significant thus be $0.021 / 2=0.0105$, the value meets the criteria $\mathrm{P}-$ Value $\leq 0.05$ then $\mathrm{H} \_$o rejected, which means the achievement of junior high school students mathematical connection capabilities usingapproach reciprocal teaching better than learning to use a regular learning at significant level 0,05. Approach Reciprocal teaching or teachingis learning to apply reverse four comprehension strategies, which conclude and summarize materials, prepare questions and solve it, explain again the knowledge that has been gained, then predicts the next question on the issues being presented to the students. The purpose of this study is to motivate students to learn independently, creatively, and more active in the learning activities. Hendriana \& Afrilianto (2014: 117). Learning class experiments using the approach of reciprocal teaching did the 7 phases or steps of learning, all seven phases approach to reciprocal teaching are:

a. Present the objectives, motivate students, and held apersepsi,

b. Presents information (materials),

c. Summing material(summarizing),

d. Develop questions or question(questiongenerating), 
e. Explaining back(clarifying),

f. Predicting matter(predicting),

g. Closing the learning.

Based on the above data processing results to produce data pretest usingstatistical test Shapiro Wilk that significant value significantly less than that specified, then H_o rejected, which means that the experimental class and the control class is derived from the sample is not normally distributed. So testing followed by non-parametrictest. Mann WhitneyFrom the test resultsthe non-parametric Mann Whitney obtained bysignificance specified more than significant, so that H_0 is received, which means there are no differences in initial capability mathematical connections junior high school students whose learning usingapproach reciprocal teaching with the learning using regular learning. The analysis of the data postes experimental class and control class by using statistical test of Shapiro Wilk which shows significant value to the experimental class over significant values are used then H_0 is accepted which means that the experimental class in normal distribution. While in the control class, menunujukan Significant Significantly less than that specified, then H_0 rejected, which means the control class is derived from the samples that are not normally distributed population. Because one of them is not normal, then proceed to the non-parametrictest. Mann WhitneyFrom the test resultsthe non-parametric Mann Whitney obtained bysignificantly significantly less than that specified, then $\mathrm{H} 0$ rejected, which means the achievement of junior high school students mathematical connection capabilities usingapproach reciprocal teaching better than learning to use a regular learning. Statistically proven that the ability of mathematical connections junior high school students experimental class is better than the control class. Learning to use the experimental class is learning usingapproach reciprocal teaching while in class learning control using commonly used by teachers in the classroom. Experimental class is better than the control class this can be possible because learning by usingapproach teaching rciprocal more motivating students to learn independently, creatively, and more active in learning. This is because theapproach reciprocal teaching implemented four comprehension strategies, which summarize or conclude materials, prepare questions and solve it, explain kembalin knowledge that has been gained, and predict problems.

\section{CONCLUSION}

Based on the research conducted on the influence ofapproach reciprocal teaching to the mathematical connection capability junior high school students can be concluded that: Achieving the ability of junior high school students with the mathematical connection usingapproach Reciprocal Teaching better than learning to use a regular learning.

\section{REFERENCES}

Gunawan, RP (2013). Ability of Mathematical Connections. [on line]. Available: proposalmatematika23.kemampuan-connection-matematik.html. (Accessed June 4, 2015)

PISA (2012). 2012. [online]. Available: http://nces.ed.gov/search/?q=skor+for+indonesia. (Accessed June 22, 2016).

Ruseffendi. ET (2010). Basics Education Research \& Field Other Non-Eksakta. Bandung: Tarsito.

Ruspiani (2000). Students ability to perform Mathematical Connections (Thesis, University of Indonesia, in 2000, not published).

Suherman \& Sukjaya. (1990). A Practical Guide to Implementing Mathematics Education Evaluation. Bandung: Wijaya Kusuma. 